\title{
Revista

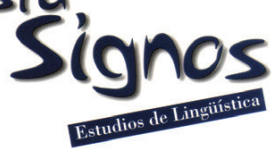

\section{Multimodal analysis of a sample of political posters in Ireland during and after the Celtic Tiger}

\author{
Análisis multimodal de una muestra de posters politicos en \\ Irlanda durante y después del Celtic Tiger
}

\author{
María Martínez Lirola \\ UNIVERSIDAD DE ALICANTE \\ ESPAÑA \\ UNIVERSIDAD DE SUDÁFRICA \\ SUDÁFRICA \\ maria.lirola@ua.es
}

Recibido: 29/IV/2014 / Aceptado: 10/VII/2015

\begin{abstract}
The aim of this research paper is to analyse the key political posters made for the campaigns of Irish political party Fianna Fáil framed in the Celtic Tiger (1997-2008) and post-Celtic Tiger years (2009-2012). I will then focus on the four posters of the candidate in the elections that took place in 1997, 2002, 2007 and 2011 with the intention of observing first how the leader is represented, and later on pinpointing the similarities and possible differences between each. This is important in order to observe the main linguistic and visual strategies used to persuade the audience to vote that party and to highlight the power of the politician. Critical discourse analysis tools will be helpful to identify the main discursive strategies employed to persuade the Irish population to vote in a certain direction. Van Leeuwen's (2008) social actor theory will facilitate the understanding of how participants are represented in the corpus under analysis. Finally, the main tools of Kress and van Leeuwen's visual grammar (2006) will be applied for the analysis of the images. The study reveals that politicians are represented in a consistently positive way, with status and formal appearance so that people are persuaded to vote for the party they represent because they trust them as political leaders. The study, thus, points out that the poster is a powerful tool used in election campaigns to highlight the power of political parties.
\end{abstract}

Key Words: Political discourse, critical discourse analysis, visual grammar, social actors, Celtic Tiger period. 


\section{Resumen}

El propósito de esta investigación es analizar los principales posters políticos empleados en las campañas electorales el partido irlandés Fianna Fáil enmarcado en los años de los períodos denominados Celtic Tiger (1997-2008) y post-Celtic Tiger (20092012). La atención se centrará en los cuatro posters del candidato a las elecciones que tuvieron lugar en 1997, 2002, 2007 y 2011 con la intención de observar cómo se representa el líder y en señalar las similitudes y diferencias entre los mismos. Esto es importante con el fin de observar las principales estrategias lingüísticas y visuales empleadas para persuadir a la audiencia para que vote al partido y para destacar al político representado. La perspectiva del análisis crítico del discurso será útil para identificar las principales estrategias discursivas empleadas para persuadir a la población irlandesa a votar en una dirección determinada. Las herramientas de la teoría de van Leeuwen (2008) sobre los actores sociales facilitará la comprensión del modo en que los participantes son representados en el corpus objeto de estudio. Finalmente, también se emplearán las principales herramientas de la gramática visual que proponen Kress y van Leeuwen (2006) al análisis de las imágenes. El estudio revela que se representa a los políticos de forma positiva, con estatus y apariencia formal de modo que se persuade a la gente para que vote al partido que representan porque confían en ellos como líderes políticos. Así, este estudio señala que el poster es una herramienta poderosa empleada por los partidos políticos en las campañas electorales.

Palabras Clave: Discurso político, análisis crítico del discurso, gramática visual, actores sociales, período Celtic Tiger.

\section{INTRODUCTION}

The Republic of Ireland has improved its socio-economic situation in the last 15 years or so. The period known as the Celtic Tiger (1997-2008) is well known for the expansion of the Irish economy due to the work and efforts of the native population or the arrival of immigrants from other countries (Baccaro \& Simone, 2004; Conlon 2007; Barrett, Bergin \& Kelly, 2009; Gaughan \& Garre, 2011; Cross \& Turner, 2012).

During the Celtic Tiger period there were three Irish elections: 1997, 2002 and 2007; these were followed by one which took place in 2011. This paper will concentrate on the elections for Taoiseach (or the Irish Prime Minister) and not on those for President. Politicians in general and the leader who became Ireland's Prime Minister during this period, Bertie Ahern (1997-2007), were proud of the socioeconomic improvements and developments that contributed to the country's visibility in Europe. Micheál Martin was the candidate for Fianna Fáil in the 2011 elections but the party did not win the elections that year. The fact that Ireland had the same Prime Minister during the whole Celtic Tiger period is significant.

During political campaigns, political leaders speak in public places, on TV, on the radio, etc. However, even if they are not present, their political posters represent them in cities and towns all over the country. For this reason, it was decided to analyse the political posters of Fianna Fáil during the Celtic and post-Celtic Tiger periods. 
Fianna Fáil was founded in 1926. Its political ideology is characterised by being Irish Nationalist and Irish Republican; it can be considered a liberal party with a centrist ideology. It is outstanding that this is the political party which has won more elections in the history of democracy in Ireland: from 1927 they have been in power 18 times, although it is true that in some of those cases they worked in coalition with other political parties (Nohlen \& Stöver, 2010).

As regards the political context of Ireland in the historical period under analysis, Fianna Fáil governed with the Progressive Democrats in 1997, 2002 and 2007, whereas in 2011 a new coalition was created between Fine Gael and the Labour Party (Nohlen \& Stöver, 2010). In 2011 Fianna Fáil suffered the worst defeat of a sitting government in the history of the Irish State.

My intention in this paper is to analyse the political posters of the candidate for Prime Minister of Ireland of Fianna Fáil during the election campaigns of 1997, 2002, 2007 and 2011. The linguistic and visual deconstruction of the posters will allow for the observation of how the political leaders are represented. In addition, the analysis will contribute to the deconstruction of the characteristics that empower politicians as leaders. This is important in order to observe the main linguistic and visual strategies used to persuade the audience to vote that party and to highlight the power of the politician. In this way, the analysis will establish a connection between the way the posters communicate and the social situation where they are used. Therefore, this study will make a contribution towards pointing out the importance of the poster in the distribution of political power.

Discourse has an important role in the political process and the political poster can be considered a powerful tool used in election campaigns to persuade the audience to vote for the political candidate represented. Johnston (2006) highlights how important it is to analyse the content of the political poster, advertising or broadcast in order to explore their function and rhetorical strategies over the course of a campaign. This paper intends to be a contribution to this area since it studies the political poster as a sample of political advertising (Kaid \& Holtz-Bacha, 2006a, 2006b). Consequently, it is important to analyse the different linguistic and visual elements in order to observe their meanings in context and their effects on the audience's ideology. This will allow deepen in the power that political parties have to persuade the audience to vote for one candidate instead of another.

Political posters are a means through which parties and candidates present themselves to the electorate. Traditionally, these posters have been used for propaganda purposes and persuasion in election campaigns (Popova, 2012). Consequently, the political poster can be used to manipulate or to inform and it is the reader who has to deconstruct the meaning of the poster adding her/his own interpretation. In this sense, political posters are effective types of propaganda whose 
true significance lies in their institutional context. Following Aulich and Sylvestrová (1999: 12):

"Political posters are part of a fluctuating discoursive structure, situated within the contexts of its exercises, as audiences and designers alike positions themselves in relation to the official culture".

After this introduction, the paper follows with the theoretical framework employed for the analysis in section two; a description of the data, aims and methodology used in section three; and the results of the analysis and an in-depth discussion in section four. Lastly, the paper finishes with some conclusions.

\section{Theoretical background}

Since our analysis is based on political posters where the photograph of the leader stands out and is crucial in conveying the meaning of the poster as a text, the theoretical background section of this paper needs to pay attention to political discourse analysis, critical discourse analysis and multimodal discourse analysis.

\subsection{Political discourse analysis}

This paper is framed in the area of political communication and political discourse analysis. Political communication, understood as the "role of communication in the political process" (Kaid, 2004a: 13), has its roots in Aristotle and Plato (Wilson, 1990). However, modern political communication is an interdisciplinary field of study that takes into consideration concepts and methodologies from political science, communication, sociology, rhetoric, journalism, history and other fields. In Chilton's words (2004: 3):

"On the one hand, politics is viewed as a struggle of power, between those who seek to assert and maintain their power and those who seek to resist it. Some states are conspicuously based on struggles for power; whether democracies are essentially so constituted is disputable. On the other hand, politics is viewed as cooperation, as the practices and institutions that a society has for resolving clashes of interest over money, influence, liberty, and the like. Again, whether democracies are intrinsically so constituted is disputed."

Politics, in general, is about finding solutions to general problems and trying to find some common ways to organize society. Following Fairclough and Fairclough (2012: 34), it:

\footnotetext{
"is about arriving cooperatively, and through some form of (collective) argumentation (deliberation), at decisions for action on matters of common concern, it is about what to do in response to public disagreement and conflict (e.g. over such issues as the distribution of scarce social goods) and in response to circumstances and events".
} 
Political discourse analysis is important in this paper because it explores the role that different genres play in the process of power enactment and in the exercise of persuading people to vote for one political party or other depending on their ideology (Chilton \& Schèaffner, 2002; Álvarez Benito, Fernández-Díaz \& Íñigo-Mora, 2009; van Dijk, 2006a, 2006b).

Other researchers focus on political discourse and the media in general (Shäffner \& Bassnett, 2010), on the press (Chen, 2007) or on television, especially on the genres of political interview, debate, public address and a generically complex media event (Fetzer \& Lauerbach, 2007). In addition, there are some on political advertising (Kaid, 2004b; Kaid \& Holtz-Bacha, 2006a). Nonetheless, there are very few studies that have concentrated on the political poster (Aulich \& Sylvestrová, 1999; Johnston, 2006; Popova, 2012). This is a very effective type of propaganda whose meaning depends on the context.

Choosing one political genre or another involves a change in the context that surrounds the text. For example, parliamentary debates normally take place in parliamentary buildings whereas political posters appear mainly in the streets, and people have to deconstruct the explicit or hidden meanings they display. Moreover, politicians speak directly in parliamentary debates whereas the political poster represents a politician who is not seen in person most of the time during the campaign. In this sense, the poster as a political practice has some specific characteristics that other political genres do not have; they are seen many times during political campaigns but they reproduce the political actors that are visually seen in them, i.e., they show the candidates for the elections although it is likely that people do not see them or do not hear them directly.

\subsection{Critical discourse analysis (CDA)}

Language is the main tool that politics uses to accomplish its ends, and the analysis of political discourse is crucial to understanding the different situations leaders can engage in. Moreover, language is a form of social behaviour and it reproduces and creates social structure; it is used in social relations in order to legitimize relationships, to establish power differences and to reproduce ideologies (Fairclough, 2002). The author already argued in 2002 that discourse is a constitutive element of political discourse, and although he focus on (verbal) language in his discussion of power in discourse, he acknowledges that there are other semiotic resources (or modes) that play a role in political discourse, such as the photograph, which is an essential resource in the political poster.

Understanding the language used in political discourse helps people understand the main strategies used by politicians to persuade voters and to observe the distribution of political power through the representation of the candidates (Fairclough \& 
Fairclough, 2012). In this sense, there is a connection between each choice done in language or in any other semiotic resource and the meanings added to them. However, this is not added arbitrarily but with a specific social purpose (Barthes, 1957). In this sense, the principles of CDA will help us understand the connection between the different linguistic and visual choices and what they communicate in context, i.e., CDA establishes relationships between discourse and society.

Critical discourse analysis studies the way language creates and reproduces social realities in order to observe possible situations of injustice, power abuse of some social groups over others, or discrimination on the basis of race, social class or sex, among others (Wodak \& Chilton, 2005; Wodak \& Meyer, 2009). In van Leeuwen's words (2009: 277),

"Critical Discourse Analysis (CDA) is based on the idea that text and talk play a key role in maintaining and legitimizing inequality, injustice and oppression in society. It uses discourse analytical methods to show how this is done, but without restricting itself to one particular discourse analytical approach".

CDA is used in this paper because it pays attention to the different choices used to create meaning in texts in order to point out how discourses are produced, with what purpose and to what extent those choices shape readers' ideology and contribute to maintaining unequal social relationships. In this sense, the principles of CDA allow deconstruct how language and power are related.

CDA proposes interdisciplinary research because social phenomena are too complex to be studied from just one discipline or field (Wodak, 1989). Moreover, there are different proponents of CDA. van Leeuwen (2008) refers to the participants of social practices as social actors and he studies the different ways in which they can be represented in discourse in order to establish relationships between discourse and context.

Van Leeuwen's approach to CDA (2008) will be applied in this research because it especially focuses on the representation of social actors in discourse as individuals or in groups, as active agents or patients; it also pays attention to their nomination, functionalization and identification, among others (see section 3). Following van Leeuwen (2008), observing social distance, social relation and social interaction is useful to understand how people appear in visuals and their interpersonal relationships with the audience.

\subsection{Multimodal discourse analysis}

Moreover, since the predominant element in political posters are the photographs of the politicians and the political poster combines images with written texts, i.e., it combines different modes of communication, it is necessary to make reference to 
multimodal discourse analysis and to the importance of visuals in the creation of meaning in multimodal texts (Baldry \& Thibault, 2006; Ventola \& Moya, 2009; O’Halloran \& Smith, 2011; O’Halloran, Tan, Smith \& Podlasov, 2011; among others).

The political poster is a very clear example of a multimodal text due to the fact that it combines more than one mode of communication: the written text and the visual. This justifies that we refer to multimodal discourse analysis in this section. The multimodal text needs to be understood as a whole in which the combination of the different modes serves the purpose of creating meaning in an effective way. Moreover, everything that is part of the multimodal text (font, place in which the image appears on the page, vocabulary and syntactic structures used, etc.) may contribute to the construction of the sense of the text and have some impact on the reader.

Therefore, this article refers to multimodality because it pays attention to the way language combines with other semiotic resources to express meaning. Following Jewitt (2009), Thibault (2000), Ventola and Moya (2009) and Parodi (2012), we are interested in the multimodal nature of present societies and in the characteristics of multimodal texts because they integrate language with other resources. For this reason, the theories of multimodality and multimodal discourse analysis (hereafter MDA) have been developed in recent decades. There is no agreement among the disciplinary community in the terminology used to refer to texts that use more than one mode or semiotic channel of communication, as O’Halloran (2011: 120) specifies that "MDA itself is referred to as 'multimodality', 'multimodal analysis', 'multimodal semiotics' and 'multimodal studies"'.

Multimodality is the term followed in this article because it is used by Kress and van Leeuwen (2006), the authors of the model of visual grammar chosen in this paper. Their approach will be followed for the analysis of the images in this article. These authors propose three main types of composition in multimodal texts that will be taken into account in this paper: (a) the 'information value', or compositional organization (e.g. centre/margin, top/bottom or left/ right); (b) 'salience', or different elements designed to catch the readers' attention (e.g. size, colour or sharpness, backgrounding or foregrounding); and c) 'framing', or presence or absence of frames that connect or disconnect elements pointing out whether they go together or not in the making of meanings.

There are challenges for multimodal research (Parodi, 2010a, 2010b; Hiippala, 2013) and therefore further research is needed. This article intends to contribute to the understanding of the multimodal nature of the political poster as the analysis presented in section 3 will make clear. 


\section{Data, aims and methodology}

The data to be analysed in this paper consists of the political posters designed to represent the leader of Fianna Fáil during the four general election campaigns that took place from 1997 to 2011. Consequently, four political posters will be analysed, three with Bertie Ahern and one in which Micheál Martin appears as the new political leader of the party after the scandal of corruption Ahern was involved in.

With regard to the compilation of the posters under analysis, it was used a very useful web page on Irish politics maintained by $\mathrm{Mr}$ Alan Kinsella (see http://irishelectionliterature.wordpress.com/), which compiles different materials related to Irish politics (newspapers articles, photographs of politicians, political posters, etc.). The general objective of this study is to analyse the political posters of three political campaigns of Fianna Fáil during the Celtic Tiger period (1997, 2002 and 2007) and the one post-Celtic Tiger (2011) in order to explore how the leaders of Fianna Fáil, i.e. Bertie Ahern and Micheál Martin are represented. The specific objectives are the following: (a) to study the main linguistic and visual characteristics used in the posters in order to persuade the audience, and (b) to observe the similarities and differences between the posters under analysis.

The main research questions are the following: How are Fianna Fáil's leaders portrayed in the posters used for their election campaigns in the period under analysis? Is there any evolution in their representation? To answer these research questions and accomplish the previous aims, the principles of critical discourse analysis (CDA), van Leeuwen's analysis of social actors (2008) and Kress and van Leeuwen's visual grammar (2006) shall be employed (see section 1) for the analysis that will be presented in section 3 .

Once the posters were compiled, we analysed the main linguistic and visual choices. The analysis had two main purposes: 1) to deconstruct the main strategies used in the representation of politicians and 2) to unveil the power they are given through the way in which they are represented in the political posters so that they persuade people to vote for the candidate represented. Special attention was paid to the relationships between the written text and the visuals in order to understand the poster as a multimodal text. In this sense, the critical analysis of the written language and the visual analysis of the photograph of the politician were combined to analyse the posters under analysis.

Following Kress and van Leeuwen's (2006) visual grammar allowed understand the way in which the different semiotic modes are used to create meaning in the political posters. The visual composition of each poster was analysed paying attention to information value, salience and framing. The analysis of the written language and the visuals was done in order to observe how the different modes express meaning. 
Having done this, van Leeuwen's (2008) critical discourse analysis of social actors was also followed. He emphasized the overall semiotic nature of discourse. His concepts of social distance, social relation and social interaction will be useful to deconstruct the politicians' representation in the posters under analysis (see section 3). A comparison of the different posters was done to observe the main similarities and differences in the representation of politicians.

Once the analysis was done following the analytical perspective of $\mathrm{CDA}$, the political poster was understood as discourse and as social practice since it communicates in a particular social context and, therefore, there is a clear relationship between the different linguistic and visual choices used to create a text and the sociopolitical situation that frames the text.

\section{Results and discussion}

This section will start with an overview of each of the political campaigns in which each poster is framed followed by a description of their main visual and linguistics features, and a comparison and contrast of the different texts in order to observe the possible evolution of the party, its values and its strategies to sell the candidate.

Regarding the different campaigns, in 1997 Fianna Fáil fought the election on the popularity of its leader, Bertie Ahern, and also focused on crime with its 'Zero Tolerance' policy. Crime was very much in the public eye as freelance journalist Veronica Guerin had been shot dead by gangsters in 1996 and there was a perception that certain criminals were 'untouchable' (Kinsella, 2013). The following paragraph from the General Election Manifesto (1997: 2) justifies why this election was so important: "[...] rarely has Ireland faced such a critical range of opportunities and threats. In the next five years, we have the choice of realising those opportunities or succumbing to those threats. The choice before the people is as stark as that".

The 2002 campaign asked people to trust the party to better Ireland's economy so that Fianna Fáil could continue working to improve Ireland's situation. The party was aware of the changes they had made in the last four years and of what still needed to be done. The following statement of the 2002 Manifesto makes this explicit (2002: 4): "We are proud of our achievements, but no Government could be expected to achieve everything it aspires to do in one term. We believe that the last five years have provided the essential foundation for building a lasting peace, prosperity and progress - but we also believe that there is much more still to be done".

The 2007 campaign focused less on Bertie Ahern and more on strengthening the country's economy, which was not a strong point in other parties such as Fine Gale and the Labour Party. They also emphasized that some life issues such as traffic, childcare, roads etc. were very much part of their agenda. In 2007, the slogan of 
Fianna Fáil's posters read 'Now, the next steps', and one could see a picture of Bertie Ahern either with an old couple or a young couple (see Figure 3). In the 2007 Manifesto (2007: 3) Bertie Ahern makes the following statement: "The time has now come for the people to decide on Ireland's future. It is a moment of unique opportunity and of historic choice. Peace and prosperity are no longer dreams, they are here and now."

In 2011, Fianna Fáil's posters were a picture of the leader, Michael Martin, with the slogan 'Real Plan, Better Future'. Michael Martin was the leader of Fianna Fáil but was not the Taoiseach (or Irish Prime Minister). He had challenged the highly unpopular Brian Cowen in a leadership battle a few weeks before the election was called. Martin became leader of Fianna Fáil but for the sake of stability, Cowen stayed on as Taoiseach. As Fianna Fáil was by then so unpopular, probably because of the corruption case Ahern was involved in, some posters had no Fianna Fáil logo on them. Most had tiny Fianna Fáil logos (Kinsella, 2013). The use of the term 'problems' makes this little idealistic panorama explicit in the 2011 Manifesto (2011: 3): "Despite the many problems we face, our country retains many great strengths. With the right policies, we can and will get through this crisis and build a better future for Ireland".

\subsection{Analysis of each poster}

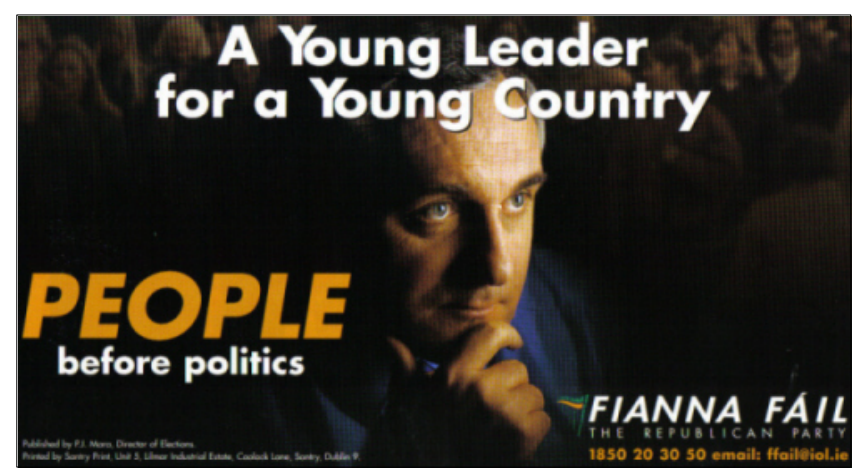

Figure 1. Political poster of the candidate for Prime Minister of the 1997 Fianna Fáil campaign.

As regards the information value of the poster, this is one to be read from the centre to the margins since Bertie Ahern appears in the centre of the poster, which contributes to highlighting that he is the main social actor represented and therefore the most salient element of the composition. The point of light in the poster is on his face. He appears serious and he looks deeply somewhere outside the poster, which can be interpreted as a symbolic way of looking forward to being the Ireland's PM in the near future. In this sense, this is considered an offer image (Kress \& van Leeuwen, 2006) because he does not interact with the audience by not looking directly. The fact that he touches his face with his right hand makes it clear that he is currently reflecting 
on something important that needs complete concentration. Moreover, the hand is the origin of some vectors that join the visual with the written text on the right and on the left.

Despite the darkness of the background, it is possible to distinguish the blurred silhouettes of people, most of which are women, behind Ahern and his dark blue jacket. It is significant that people appear backgrounded and after the politician although the written message, where the word 'people' is in capital letters, states that they are before politics. The dark colours of the visual contrast with the white and orange letters of the written text; orange is one of the colours of the small flag that symbolises the party (here before the name of the party at the bottom of the text). The dark background suggests that Ireland is in semi-darkness and it could be understood as a big challenge for Ahern, whose main aim is to win the elections and improve the country's situation.

On the one hand, it is clear that the logo and the name of the party appear on the right and at the bottom, the place for the most important information. On the other hand, the slogan is placed on the left, where known or less important information is located. However, the fact that the word 'people' appears in capital letters and in a bigger font than the rest of the written text helps to highlight the slogan. It matches visually with the people in the background. The very small written text behind "People before politics" just makes references to whom has published and printed the poster.

The fact that Ahern is referred to as "A Young Leader for a Young Country" at the top of the poster is outstanding for several reasons: first of all, the repetition of the adjective 'young' to refer to the politician and to Ireland point out that this candidate is the ideal one for this historical moment in Ireland. In addition, the adjective and the two nouns that follow it (leader and country) appear capitalized as a way of emphasizing this part of the slogan. Secondly, the fact that this sentence appears covering part of Ahern's head makes it clear who the young leader is and establishes a clear connection between the written text and the visual. Thirdly, this phrase and the other two examples of written text surrounding Bertie Ahern's face create a triangle that contributes to emphasising his presence. 


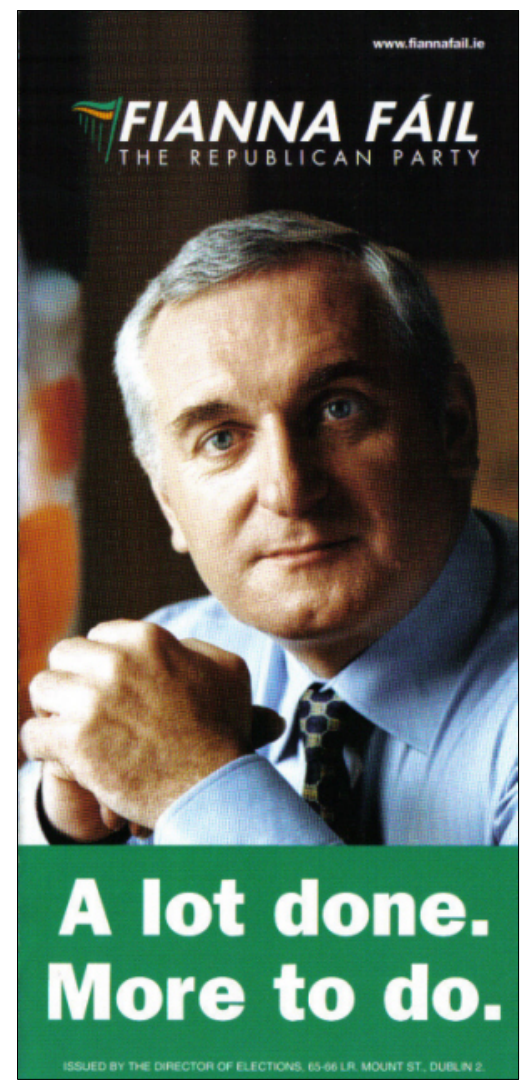

Figure 2. Political poster of the candidate for Prime Minister of the 2002 Fianna Fáil campaign.

The information value of this poster is different from the previous one because this is read from top to bottom (Kress \& van Leeuwen, 2006) because the name of the party and part of the head of Bertie Ahern appear at the top of the poster, which makes the reader start reading this multimodal text from the top. At the very top of the poster we find the web page of the party in a small size; this is followed by the name of the party in bold capital letters and, right below, the photograph of Bertie Ahern. The slogan of this campaign appears at the end of the poster "A lot done. More to do".

The photograph is the most salient element of the composition due to its size and to the message it conveys: the politician appears foregrounded, the background is blurred but lighter than the one in the previous poster; the fact that he is the only social actor represented contributes to emphasizing the candidate. Ahern looks directly at the audience, which is a clear way of interacting with them and requesting an answer or rather an action from them: their vote for Fianna Fáil. This can be considered a demand image (Kress \& van Leeuwen, 2006), which contrasts with the one presented in the previous poster. Ahern looks less serious and more relaxed and 
sure than in the last poster. Moreover, the posture of his hands shows that he is a confident leader who is willing to continue doing things for Ireland. In this sense it is outstanding that, although he is also wearing smart clothes (a shirt and a tie), on this occasion he has taken off his jacket, making thus his image as a politician more approachable than in the previous poster; it can also be understood that he is working and he takes off his jacket in order to be more comfortable. The hands are important in the composition because there are different vectors that join them with the rest of the multimodal text: with the slogan at the bottom, with Ahern's nose in the centre and with the name of the party at the top, which is preceded by the party's symbol; it has the shape of a harp, which is a typical Irish instrument.

The photograph of Bertie Ahern is framed in this visual between the two written texts that surround him: the party he is representing and the positive slogan used to persuade people to vote for Fianna Fáil so that the party can be in power again; similar space is given to both sections where a written message is conveyed. Like in the previous poster, white is also the colour used for the letters. This colour contrasts with the black background of the top of the poster and the green of the bottom. Green is not chosen at random because it is one of the two colours that appear in the small flag that is the symbol of Fianna Fáil. As in Figure 1, the small flag also appears before the name of the party. The colours of Ireland's flag are white, orange and green. In this way we observe a cohesive use of colours.

As regards the written text, the repetition of the verb 'do' in two different verbal forms (done and to do), highlight all the positive things done by the party in the past and evoke the necessity of continuing to do things in the future with the support of Irish people. In addition, there are several examples of ellipsis in the written text that make the slogan easy to remember and follow: what has been done is not specified (but it is assumed that they have been positive things) and who has done the things is also not mentioned although it is obvious that the answer is in the other two sections of the poster: Fianna Fáil and Ahern.

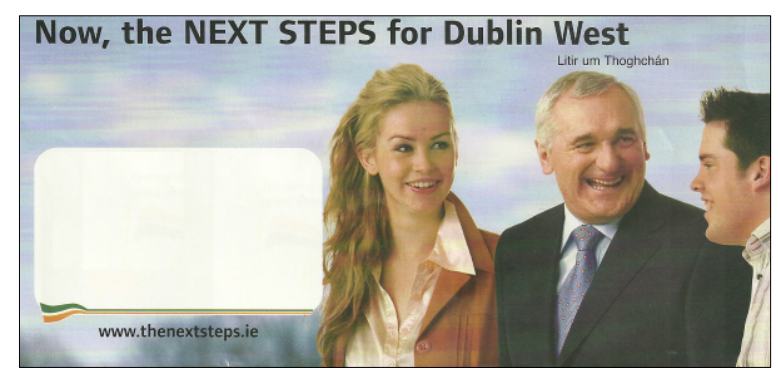

Figure 3. Political poster of the candidate for Prime Minister of the 2007 Fianna Fáil campaign. 
The 2007 campaign is different from the previous two because the candidate does not appear alone in the poster but accompanied by two young people, i.e. this is a way of emphasizing the idea of teamwork instead of simple leadership. The image of the social actors next to Ahern is that of typically Irish people (white skin, blonde hair, etc.). The information value of the poster is different from the previous two because the three social actors represented appear on the right, which is where the most important information is placed. On the right there is the web page of the campaign, and the colours green, white and orange symbolizing the party and the country. Here the harp has disappeared, maybe because the party has changed its institutional image or because it is the country itself that wants to be highlighted and the fact the party is working for the homeland.

There are different vectors joining the three social actors, for example, their heads and their noses, among others. The fact that Ahern appears between the young couple is not a random decision because his figure joins both. As occurs in Figure 1, he appears again wearing his jacket as a symbol of formality. Moreover, his head is also connected through a vector with the slogan placed at the beginning of the text. This slogan is less specific than the previous two because the reference to the next steps is too general.

The colour of the slogan matches the colour of Ahern's jacket, which adds cohesion to the composition. In addition, the woman's jacket contrasts with the one worn by Ahern. Moreover, it is significant that her jacket is orange, which is one of the colours that appears in the logo of the party. This detail suggests that the young woman belongs to Fianna Fáil. There is no doubt that the three social actors represented are the most salient element in the poster. There is a relationship between the slogan and the people who appear in the photograph since it is they who are the people who will continue working for the next steps towards developing Ireland.

This would be another example of an offer visual (Kress \& van Leeuwen, 2006) because the three people do not look at the audience. The woman and Ahern look at the man in the corner on the right hand side of the text. It is outstanding that the three are smiling, which contributes to adding a positive view to the multimodal text and to Fianna Fáil. The different social actors and the slogan are clearly highlighted because the background is also blurred as is the case in the previous posters. 


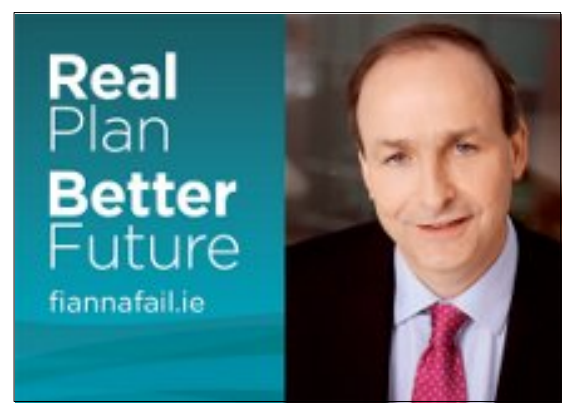

Figure 4. Political poster of the candidate for Prime Minister of the 2011 Fianna Fáil campaign.

This political poster shows that there is a significant change in the way the candidate for Prime Minister is advertised, in the colours used, in the format, etc. This could be due to having a different candidate or to changes in marketing. The new candidate for the Fianna Fáil election campaign in 2011, Micheál Martin, appears alone in the poster under analysis. The information value of the composition shows that the poster is divided in two sections: the written text appears on the left and the photograph on the right. It is read from top to bottom because the candidate's head appears at the top of the composition.

Martin is the only social actor in the text; he appears on the right, again the place where the most important information is positioned, and therefore he is the most salient element of the poster. He looks directly at the audience requesting an action a vote. The background of the right part of the poster is blurred and dark, which contrasts with Martin's face as the main focus of light in the poster. He wears smart clothes; in this case his white shirt and red tie contrast with the blue shirts and dark ties used by Ahern in the previous posters. We can see a man who offers himself as candidate without using visual support. We see a middle-aged elegant man who appears without promises except the logo and without any references that can connect him with Ahern.

With regards to the written text, the slogan of the campaign "Real Plan, Better Future" appears on the left. This is followed by the web page of the party. Just like in Figure 1 and 2, white is also the colour chosen for the written text in order to contrast with the candidate's jacket. The words 'real' and 'better' are in bold capital letters. This poster is also different from the previous ones because the written message is not linked to the candidate and what he has done. There is no sense of continuity but aims of improving a social political situation that had not been properly planned and was not realistic. There are some examples of ellipsis in the slogan as a way of making it catchy and clear since the complete sentence could be something like: we/I have a real plan in order to have a better future. 
There are different vectors that join the slogan with Martin's photograph and with the name of the party, which makes it clear that the different elements of this multimodal text are connected. For example, the words of the slogan are joined with Martin's face. Consequently, there is a symbolic identification between the party, the slogan it has and Martin as its political leader. As already mentioned when analyzing Figure 2, this would be another example of a demand visual in which the politician requests a direct answer from the viewer: her/his vote.

\subsection{Comparison of the four posters: Similarities and differences}

Comparing the posters under analysis, it is clear that the person represented as the main social actor in the four is Fianna Fáil's leader and, therefore, there is a clear reference to his function in society as the political party leader. Following van Leeuwen's (2008) classification of social actors, this would be included in the category of functionalization and identification because it refers to social actors in terms of their activity or their identity; thus, Ahern and Martin are portrayed as politicians and party leaders.

Moreover, the politician's identity is highlighted due to the fact that he is represented alone in three of the four texts under analysis, i.e. the political leader is individualised and presented as an individual (van Leuween, 2008), whereas it is only in Figure 3 that he appears in a group, i.e. in van Leeuwen's terms (2008), he is collectivized, although Ahern is older and has political responsibility. In this sense, it is clear that in three of the four posters, the politician is the protagonist of the text (see Figures 1, 2 and 4), and therefore he is the centre of attention and pointed out as evidently being leader of the party.

In addition, the political leaders represented appear as active in the posters in which they look directly at the audience requesting to be voted (see Figures 2 and 4) or when they appear to be doing something as in Figure 3, in which there is interaction with the other social actors represented, thereby signalling that Ahern is close to people. However, in Figure 1, Bertie Ahern seems passive by not looking at the audience, which contrasts with the way he is represented in the other texts.

Nomination is a category that makes reference to the unique identity of social actors by mentioning the names. Although the names of politicians do not appear in the posters, there is no doubt that the two political leaders represented can be easily identified with their names (i.e. Bertie Ahern and Micheál Martin) by seeing their faces. It is obvious that the bodies of the different social actors in the posters are cut out, i.e. there is not a single visual in which the whole body of the politician can be seen in full. Normally, the top part of the body, especially the face, is the one which is emphasized in visuals as is the case in the texts under analysis. 
Considering social distance, the different social actors represented are not presented as distanced from people. The individuality of the political leader is emphasized by using close up shots in Figures 1,2 and 3; he appears foregrounded in these texts and is represented as approaching the audience. As for the social relation between both politicians and the viewer, there is an invitation of cooperation by voting for them in the general elections; this is one of the most important purposes of the political poster. With respect to social interaction, the main factor to be considered is whether the social actors look at the viewer or not. Consequently by looking directly at the viewer, we are invited to become involved in the action as it happens in Figures 2 and 4 (see section 4.1). Looking directly to the audience helps to establish a dialogue or an explicit demand, which consists of trusting Ahern and Martin in this case.

The following table shows the main similarities and differences we have referred to in the previous paragraphs. This is a clear way of observing the main characteristics of the posters analysed and what they have in common in the representation of the political leaders:

Table 1. Comparison of the four posters.

\begin{tabular}{|c|c|c|c|c|c|c|}
\hline & $\begin{array}{c}\text { Leaders as } \\
\text { the main } \\
\text { social } \\
\text { actor }\end{array}$ & $\begin{array}{c}\text { Leaders } \\
\text { alone and } \\
\text { serious }\end{array}$ & $\begin{array}{c}\text { Leaders } \\
\text { active }\end{array}$ & $\begin{array}{c}\text { Leaders } \\
\text { with their } \\
\text { bodies cut }\end{array}$ & $\begin{array}{c}\text { Leaders in } \\
\text { close up } \\
\text { shots }\end{array}$ & $\begin{array}{c}\text { Leaders } \\
\text { look at the } \\
\text { audience }\end{array}$ \\
\hline Figure 1 & $\mathrm{X}$ & $\mathrm{X}$ & & $\mathrm{X}$ & $\mathrm{X}$ & \\
\hline Figure 2 & $\mathrm{X}$ & $\mathrm{X}$ & $\mathrm{X}$ & $\mathrm{X}$ & $\mathrm{X}$ & $\mathrm{X}$ \\
\hline Figure 3 & $\mathrm{X}$ & & $\mathrm{X}$ & $\mathrm{X}$ & $\mathrm{X}$ & \\
\hline Figure 4 & $\mathrm{X}$ & $\mathrm{X}$ & $\mathrm{X}$ & $\mathrm{X}$ & & $\mathrm{X}$ \\
\hline
\end{tabular}

There are other differences between the four posters: the fact that the leader looks serious or pensive in three of the four posters is significant, which contrasts with the representation of Bertie Ahern in Figure 3, where one can see him smiling openly and with a couple of young people. Although both politicians wear smart clothes, Ahern prefers a blue jacket, tie or shirt, whereas Martin uses a white shirt and a red tie. In this way, the changes in his style help to emphasize that Fianna Fáil has changed his leader, that the message of the party has changed and that no links must be found between the past and the future.

The four posters are framed and therefore the different linguistic and visual elements create a unity in each text. The texts under analysis have been created in a different way, i.e. they have different information value (see section 4.1). The positions of the slogan are also different: on the left in Figure 1, at the bottom on Figure 2, at the top on Figure 3 and on the left in Figure 4. Moreover, an evolution in the representation of Bertie Ahern can be observed: he started being represented as a very serious and smart man, and he evolves to be seen as more approachable: in Figure 2 he wears no jacket and in Figure 3 he is smiling. With respect to colours, presenting 
both politicians wearing similar colour clothes contributes to homogenising them and making clear that they belong to the same party.

The four slogans of Fianna Fáil's political campaigns under analysis are the following: "People before politics" (1997), "A lot done. More to do" (2002), "Now, the next steps" (2007) and "Real Plan. Better Future" (2011). It is obvious that the main characteristics of the slogans are that they are short (there are several examples of ellipses), catchy and they use positive language in order to persuade the audience to vote for the party and associate it with positive actions.

The first slogan "People before politics" points out the human side of the political party by emphasizing the importance of people in the campaign. The 2002 slogan " $\mathrm{A}$ lot done. More to do" suggests the main actions done by Fianna Fáil and the ones that they will do. "Now, the next steps", used in the 2007 campaign, is less explicit than the previous two, which shows that the party was not at its best and did not have such clear objectives as in the previous campaign. Finally, "Real Plan. Better Future" seems to establish a contrast with the previous ones in the sense that now it is clear that the party has a real plan that will bring a better future to Ireland, suggesting that this was not so before.

The analysis shows that the politicians that appear in the posters analysed are represented in a consistently positive way so that people trust them and therefore vote for the party they represent. This is a common characteristic used in political discourse to persuade people see politicians as people who are secure and empowered.

\section{CONCLUSIONS}

This paper has analysed how the political leaders of one of the most important Irish political parties have been represented in the political posters used in the last four political campaigns. Critical discourse analysis, Van Leeuwen's (2008) analysis of social actors and Kress and van Leeuwen's (2006) visual grammar have been used to deconstruct the image of the leaders. The analysis has shown that the politicians appear represented mainly in a positive way, as active individuals, with status and with formal appearance. They are social actors with power to persuade people to vote them in election campaigns.

The written language of the posters analysed shows the characteristics of political discourse, whose main purpose is to persuade the audience to vote for Fianna Fáil: use of ellipsis, positive language, repetitions, and short phrases are the main features of the slogans found in the posters. In this sense, the different slogans and the visual representation of Bertie Ahern and Micheál Martin as secure political leaders suggest the idea of Ireland as a European country that was in a process of socio-economic development in Europe and whose expansion was progressively growing. 
The different visual and linguistic characteristics found in the posters show that the poster is an example of a multimodal text framed inside political genres and, as such, it is a powerful tool used in election campaigns in order to point out the political power that a party may have. It is also a text type used to persuade people to vote and to convince people of the convenience of choosing the candidate proposed by the way $\mathrm{s} /$ he is constructed linguistically and visually. Consequently, the poster as a sub-genre inside political genres is not only defined in terms of its structure and the multimodal elements that create it but also in terms of the political context that frames it. In this sense, the analysis presented in this paper is not just a contribution to discourse studies but also to political science and, in a more general sense, to the social sciences.

The four posters analysed interact with the audience through the different visual and linguistic choices that appear in them. The political messages presented in the posters are explicit because the slogans are very catchy and clearly chosen to persuade the audience to vote for this party instead of any other and the photographs represent the leader of the party as a candidate to be the president of Ireland in the Celtic and post-Celtic Tiger period. The producers of the posters take into consideration the audience that will see the posters, i.e. Fianna Fáil, the receivers, i.e. the Irish population who had to vote, the message itself, i.e. the political poster as a type of propaganda before elections, the channel of communication, i.e. mainly the Irish streets, and the effect the posters should produce, which was to persuade people to vote for the candidates represented. 


\section{BIBLIOGRAPHICAL REFERENCES}

Álvarez-Benito, G., Fernández-Díaz, G. \& Íñigo-Mora, I. M. (Eds.). (2009). Discourse and politics. Newcastle upon Tyne: Cambridge Scholars Publishers.

Aulich, J. \& Sylvestrová, M. (1999). Political posters in central and eastern Europe, 1945-95: Signs of the times. Manchester: Manchester University Press.

Baccaro, L. \& Simone, M. (2004). The Irish social partnership and the 'Celtic Tiger' phenomenon. Discussion Paper Series, 154. Geneva: International Labour Organization [on line]. Available in: http://eprints.lse.ac.uk/33566/.

Baldry, A. \& Thibault, P. J. (2006). Multimodal transcription and text analysis. London: Equinox.

Barrett, A., Bergin, A. \& Kelly, E. (2009). Estimating the impact of immigration on wages in Ireland. Discussion Paper No. 4472. Bonn: The Institute for the Study of Labor [on line]. Available in: http://www.esri.ie/UserFiles/publications/20090930094315/WP318.pdf.

Barthes, R. (1957). Mythologies. Paris: Editions du Seuil.

Chen, L. (2007). Negatives and positives in the language of politics attitudes towards authority in the British and Chinese press. Journal of Language and Politics, 6(3), 475-502.

Chilton, P. A. (2004). Analysing political discourse: Theory and practice. London: Routledge.

Chilton, P. \& Schèaffner, C. (Eds.) (2002). Politics as text and talk: Analytic approaches to political discourse. Amsterdam and Philadelphia: John Benjamins.

Conlon, D. (2007). The nation as embodied practice: Women, migration and the social production of nationhood in Ireland. Unpublished Ph.D. Thesis, New York, City University of New York.

Cross, C. \& Turner, T. (2012). Immigrant experiences of fairness at work in Ireland. Economic and Industrial Democracy, 34(4), 575-959.

Fairclough, N. (2002). Language and power. Second edition. London: Macmillan.

Fairclough, I. \& Fairclough, N. (2012). Political discourse analysis. A method for advanced students. London and New York: Routledge.

Fetzer, A. \& Lauerbach, G. E. (Eds.). (2007). Political discourse in the media. Cross-cultural perspectives. Amsterdam and Philadelphia: John Benjamins.

Fianna Fáil. (1997). Fianna Fáil general election Manifesto 1997. Dublin: Fianna Fáil. 
Fianna Fáil. (2002). Fianna Fáil Manifesto 2002. A Lot Done. More to Do. Dublin: Fianna Fáil.

Fianna Fáil. (2007). Fianna Fáil Manifesto 2007. Now, the Next Steps. Dublin: Fianna Fáil.

Fianna Fáil. (2011). Fianna Fáil Manifesto 2011.Real Plan. Better Future. Dublin: Fianna Fáil.

Gaughan, L. \& Garre, P. M. (2011). The 'most twisted and unaccountable force in the state'? Newspaper accounts of social work in the Republic of Ireland in troubled times. Journal of Social Work, 12(3), 267-286.

Hiippala, T. (2013). The interface between rhetoric and layout in multimodal artefacts. Literary and Linguistic Computing, 28(3), 461-471.

Jewitt, C. (2009). Different approaches to multimodality. In C. Jewitt (Ed.), The Routledge handbook of multimodal analysis (pp. 28-39). London: Routledge.

Johnston, A. (2006). Methodologies for the study of political advertising. In L.L. Kaid \& C. Holtz-Bacha (Eds.), The Sage handbook of political discourse (pp. 15-34). London: Sage.

Kaid, L. L. (2004a). Introduction and overview of the field. In L. L.Kaid (Ed.), Political communication research (pp. xiii-xviii). London and New Jersey: Lawrence Erlbaum.

Kaid, L. L. (2004b). Political advertising. In L.L. Kaid (Ed.), Handbook of political communication research (pp. 155-202). Mahwah, New Jersey: Lawrence Earlbaum.

Kaid, L. L. \& Holtz-Bacha, C. (Eds.). (2006a). The Sage handbook of political advertising. Thousand Oaks: Sage.

Kaid, L. L. \& Holtz-Bacha, C. (2006b). Political advertising in international comparison. In L.L. Kaid and C. Holtz-Bacha (Eds.), The Sage handbook of political discourse (pp. 3-13). London: Sage.

Kinsella, A. (2013). Irish Election Literature [on line]. Available in: http://irishelectionliterature.wordpress.com/.

Kress, G. \& van Leeuwen, T. (2006). Reading images: The grammar of visual design. Second edition. London: Routledge Press.

Nohlen, D. \& Stöver, P. (2010). Elections in Europe: A data handbook. London: Nomos. 
O’Halloran, K. L. (2011). Multimodal discourse analysis. In K. Hyland \& B. Paltridge (Eds.), The Continuum companion to discourse analysis (pp. 120-137). London and New York: Continuum.

O’Halloran, K. L., Tan, S., Smith, B. A. \& Podlasov, A. (2011). Multimodal analysis within an interactive software environment: Critical discourse perspectives. Critical Discourse Studies, 8, 109-25.

O'Halloran, K. \& Smith, B. (Eds.). (2011). Multimodal studies. Exploring issues and domains. London: Routledge.

Parodi, G. (2010a). Research challenges for corpus cross-linguistics and multimodal texts. Information Design Journal, 18, 69-73.

Parodi, G. (2010b). Multisemiosis y lingüística de corpus: Artefactos (multi)semióticos en los textos de seis disciplinas en el corpus pucv-2010. Revista de Lingüística Teórica y Aplicada, 48(2), 33-70.

Parodi, G. (2012). University genres and multisemiotic features: Accessing specialized knowledge through disciplinarity. Forum Linguist. Florianópolis, 9(4), 259-282.

Popova, M. (2012). Presidential campaign posters: 200 years of election art. A brief visual history of political propaganda design [on line]. Available in: http://www.brainpickings.org/index.php/2012/06/04/presidentialcampaign-posters/.

Shäffner, C. \& Bassnett, S. (2010). Political discourse, media and translation. Newcastle upon Type: Cambridge Scholars Publishers.

Thibault, P.J. (2000). The multimodal transcription of television advertisement: Theory and practice. In A. Baldry (Ed.), Multimodality and multimediality in the distance learning age (pp. 311-385). Campobasso: Palladino Editore.

van Dijk, T. A. (2006a). Politics, ideology and discourse. In R. Wodak (Ed.), Elsevier encyclopedia of language and linguistics (pp. 728-740). Volume on Politics and Language. Oxford: Elsevier.

van Dijk, T. A. (2006b). Ideology and discourse analysis. Journal of Political Ideologies, $11(2), 115-140$.

van Leeuwen, T. (2008). Discourse and practice. New tools for critical discourse analysis. Oxford: Oxford University Press.

van Leeuwen, T. (2009). Critical discourse analysis. In J. Renkema (Ed.), Discourse, of course. An overview of research in discourse studies (pp. 277-292). Amsterdam and Philadelphia: John Benjamins. 
Ventola, E. \& Moya, J. (Eds.). (2009). The world told and the world shown: Multisemiotic issues. Hampshire: Palgrave Macmillan.

Wilson, J. (1990). Politically speaking. Oxford: Blackwell.

Wodak, R. (1989). Language, power and ideology. Studies in political discourse. Amsterdam and Philadelphia: John Benjamins.

Wodak, R. \& Chilton, P. (Eds). (2005). A new agenda in (critical) discourse analysis. Amsterdam and Philadelphia: John Benjamins.

Wodak, R. \& Meyer, M. (Eds.). (2009). Methods of critical discourse analysis. London: Sage Publications. 